\title{
Sulfur modulates yield and storage proteins in soybean grains
}

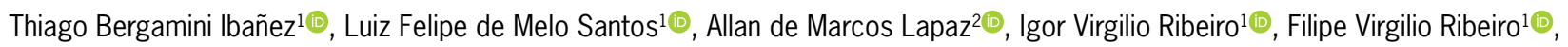
André Rodrigues dos Reis ${ }^{3}$, Adônis Moreira ${ }^{4}$, Reges Heinrichs ${ }^{*}{ }^{*}$ (i)

\begin{abstract}
"Universidade Estadual Paulista "Júlio de Mesquita Filho" / FCAT - Depto. de Ciência do Solo, Rod. Comandante João Ribeiro de Barros, km 651 - Campus de Dracena 17900-000 - Dracena, SP - Brasil.

¿Universidade Estadual Paulista “Júlio de Mesquita Filho" / FEIS - Depto. de Biologia e Zootecnia, R. Monção, 226 Zona Norte - 15385-000 - Ilha Solteira, SP - Brasil. 3Universidade Estadual Paulista “Júlio de Mesquita Filho" / FCE - Depto. de Produção Vegetal, R. Domingos da Costa Lopes, 780 - 17602-496 - Tupã, SP - Brasil.

${ }^{4}$ Embrapa Soja - Setor de Fertilidade do Solo, Rod. Carlos João Strass, s/n - 86001-970 - Londrina, PR - Brasil.

*Corresponding author <reges.0605@gmail.com>
\end{abstract}

Edited by: Lincoln Zotarelli

Received January 25, 2019

Accepted June 26, 2019
ABSTRACT: This study evaluated the nutritional quality, yield, and storage protein modulation in soybean grains in response to levels and sources of sulfur $(S)$ in a dystrophic Ultisol. We used five levels of $S\left(0,50,100,150\right.$ and $\left.200 \mathrm{mg} \mathrm{kg}^{-1}\right)$ and four sources of $S$ (elemental $S$ pastille ESPA, gypsum - GY, gypsite - Gl and elemental S powder - ESPO). Plants treated with 50 mg kg-1 of GY, Gl, and ESPO and $200 \mathrm{mg} \mathrm{kg}^{-1}$ of ESPA had the largest grain yield values. Low S supply resulted in lower yields for all $S$ sources tested. Sulfur deficiencies were observed at all levels for ESPA, resulting in lower concentrations of globulin and higher concentration of glutelin and albumin in the grains, possibly because the $S$ content in the leaf was below the range adequate for soybean, leading to in lower yield values. In general, the application of S sources (GY, Gl, and ESPO) increased all protein fractions. The results show that proper application of $S$ is essential to optimize soybean yield and increase storage proteins in the grains. The granulometry of ESPA and ESPO fertilizers was a key factor for the availability of $S$ to soybean plants. This study presents relevant information on $S$ fertilization of soybeans, which could provide better grain nutritional quality and increased storage proteins with benefits to animal health.

Keywords: Glycine max, plant nutrition, elemental sulfur, sulfate

\section{Introduction}

Soybean (Glycine max) grains are the main source of vegetable protein worldwide and contain up to $45 \%$ of protein (Liu et al., 2008). The high protein content in soybean grains is directly connected to their nutritional value, mainly due to the contents of sulfur $(\mathrm{S})$ and nitrogen (N). Legumes have different fractions of storage proteins (albumin, globulin, prolamin, and glutelin) that can be influenced by S fertilization (Chandra and Pandey, 2016).

Nitrogen acquisition in soybean plants occurs via biological N fixation (Cazzato et al., 2012; Habtemichial et al., 2007). The process of uptake and metabolism of $\mathrm{N}$ and $\mathrm{S}$ in the plant depends on a group of iron-sulfur proteins (Fe-S) (Balk and Pilon, 2011). Fe-S proteins are also related to other physiological processes fundamental for plant life, such as catalytic, regulatory, and structural activities (Balk and Pilon, 2011; Capaldi et al., 2015).

Protein synthesis is highly dependent on $\mathrm{N}$ and S (Jamal et al., 2010). Specifically, S is integrated as an $S$ radical into amino acids (methionine and cysteine), which are important for tertiary structure determination and protein synthesis. Therefore, application of fertilizers containing S to S-deficient soils is essential for an adequate $\mathrm{N}: \mathrm{S}$ ratio in the plant, optimizing yield and grain quality (Jamal et al., 2010; Steinfurth et al., 2012).

Recent studies show that in the main soybean producing countries, namely Brazil, the United States, and Argentina, S-deficient soil is a main concern for soybean crops (Salvagiotti et al., 2012; Divitoet al., 2015). This is due to increased soil use and the use of
S-free fertilizers, which tend to augment $\mathrm{S}$ deficiencies in crops (Vermeiren et al., 2018).

Because $\mathrm{S}$ is absorbed by roots as inorganic sulfate (Aziz et al., 2016), different $S$ sources may interact with the soil and interfere with $S$ uptake. Fertilizers that provide $S$ in the form of sulfate can be readily absorbed. On the other hand, S is only absorbed after undergoing the oxidation process, which may be favorable for a balanced and continuous supply during the crop cycle (Degryse et al., 2016; Degryse et al., 2017). This study evaluated the nutritional quality, yield, and storage protein modulation in soybean grains in response to the $\mathrm{S}$ levels and sources in a dystrophic Ultisol.

\section{Material and Methods}

\section{Experimental site}

The experiment was carried out under greenhouse conditions in the city of Dracena, São Paulo State, Brazil, (latitude $21^{\circ} 29^{\prime} \mathrm{S}$ and longitude $51^{\circ} 2^{\prime} \mathrm{W} ; 396 \mathrm{~m}$ altitude), using soybean variety 'Potência' RR, Glycine $\max (\mathrm{L}$.$) Merril, as test crop from Sept 2016$ to Feb 2017.

\section{Experimental design}

The experimental design was completely randomized and arranged in a $5 \times 4$ factorial scheme, with five levels of $\mathrm{S}\left(0,50,100,150\right.$ and $\left.200 \mathrm{mg} \mathrm{kg}^{-1}\right)$ and four $\mathrm{S}$ sources. These sources were elemental S pastilles (ESPA, $90 \% \mathrm{~S}$ ), with size 1-4 mm, gypsum (GY) residue from the manufacture of phosphate fertilizers $(24 \% \mathrm{Ca} ; 17 \% \mathrm{~S})$, gypsite (GI), ground natural rock $(24 \% \mathrm{Ca} ; 17 \% \mathrm{~S})$, and elemental S powder (ESPO, $95 \% \mathrm{~S}$ ), with particles $<0.1 \mathrm{~mm}$. 


\section{Crop conditions}

The soil was a dystrophic Ultisol, with the following chemical attributes: $\mathrm{pH}=4.6$, organic matter $=17.0 \mathrm{~g}$ $\mathrm{kg}^{-1}, \mathrm{P}=6.0 \mathrm{mg} \mathrm{kg}^{-1}, \mathrm{~K}=1.2 \mathrm{mmol}_{\mathrm{c}} \mathrm{kg}^{-1}, \mathrm{Ca}=6.0 \mathrm{mmol}_{\mathrm{c}}$ $\mathrm{kg}^{-1}, \mathrm{Mg}=3.0 \mathrm{mmol}_{\mathrm{c}} \mathrm{kg}^{-1}, \mathrm{~S}=7.0 \mathrm{mg} \mathrm{kg}{ }^{-1}$; potential acidity $21.0 \mathrm{mmol}_{\mathrm{c}} \mathrm{kg}^{-1}, \mathrm{Al}=3.0 \mathrm{mmol}_{\mathrm{c}} \mathrm{kg}^{-1}$, sum of bases $10.2 \mathrm{mmol}_{\mathrm{c}} \mathrm{kg}^{-1}$, cation exchange capacity $(\Sigma \mathrm{K}, \mathrm{Ca}$, $\mathrm{Mg}, \mathrm{H}+\mathrm{Al})=31.2 \mathrm{mmol}_{\mathrm{c}} \mathrm{kg}^{-1}$ and base saturation $[(\Sigma \mathrm{K}$, $\mathrm{Ca}, \mathrm{Mg}) /(\Sigma \mathrm{K}, \mathrm{Ca}, \mathrm{Mg}, \mathrm{H}+\mathrm{Al})] \times 100(\mathrm{~V})=33 \%$. The determinations were as described by Raij et al. (2001): P, K, $\mathrm{Ca}$ and $\mathrm{Mg}$ determinations were performed using the ion exchange resin method, $\mathrm{SO}_{4}^{-2}$ was determined by extraction with $\mathrm{Ca}\left(\mathrm{K}_{2} \mathrm{PO}_{4}\right)_{2}$ solution, $\mathrm{pH}$ was determined in $\mathrm{CaCl}_{2}$, organic matter (OM) was determined by colorimetry, potential acidity was determined with ShoemakerMcLean-Pratt (SMP) buffer (Shoemaker et al., 1961) and $\mathrm{Al}$ was determined by $\mathrm{KCl}$. The $\mathrm{Cu}, \mathrm{Fe}, \mathrm{Mn}$ and $\mathrm{Zn}$ were determined by extracts in diethylenetriaminepentaacetic acid-triethanolamine (DTPA-TEA) at $\mathrm{pH} 7.3$ and $\mathrm{B}$ was determined with hot water.

The soil was sampled from $0-0.20 \mathrm{~m}$ at depth for a composite sample. The soil was crumbled, air-dried, and sieved $(4.0 \mathrm{~mm})$. The base saturation of soil was increased to $70 \%$ (Quaggio et al., 1985) by adding calcium carbonate $\left(\mathrm{CaCO}_{3}\right)$ and magnesium carbonate $\left(\mathrm{MgCO}_{3}\right)$, p.a. reagents at 3:1. The soil with carbonate salts was then incubated in the pots for 30 days awaiting reactions, while maintaining moisture at $80 \%$ of field capacity. At the end of the incubation period, the soil was air-dried for seven days.

\section{Experimental procedures}

The quantity of $S$ sources was calculated based on the total concentration in the fertilizer material. The $S$ sources were mixed with $4 \mathrm{~kg}$ of soil per pot $(21.5 \mathrm{~cm}$ in diameter and $17 \mathrm{~cm}$ in height). The treatments were evaluated in four replicates totalling 80 pots. The soil density was $1.3 \mathrm{~g} \mathrm{~cm}^{-3}$.

Fertilization was carried out with the following levels and sources: $10 \mathrm{mg} \mathrm{kg}^{-1} \mathrm{~N}$ in the form of $\mathrm{CO}\left(\mathrm{NH}_{2}\right)_{2}$, $200 \mathrm{mg} \mathrm{kg}^{-1} \mathrm{P}$ in the form of $\mathrm{Ca}\left(\mathrm{H}_{2} \mathrm{PO}_{4}\right)_{2} \cdot \mathrm{H}_{2} \mathrm{O}, 150 \mathrm{mg}$ $\mathrm{kg}^{-1} \mathrm{~K}$ in the form of $\mathrm{KCl}, 0.5 \mathrm{mg} \mathrm{kg}^{-1} \mathrm{~B}$ in the form of $\mathrm{H}_{3} \mathrm{BO}_{3^{\prime}} 0.05 \mathrm{mg} \mathrm{kg}^{-1} \mathrm{Co}$ in the form of $\mathrm{CoCl}_{2} \cdot \mathrm{H}_{2} \mathrm{O}, 1.0$ $\mathrm{mg} \mathrm{kg}^{-1} \mathrm{Cu}$ in the form of $\mathrm{CuSO}_{4} \cdot 5 \mathrm{H}_{2} \mathrm{O}, 0.05 \mathrm{mg} \mathrm{kg}^{-1} \mathrm{Mo}$ in the form of $\mathrm{H}_{2} \mathrm{MoO}_{4}, 0.05 \mathrm{mg} \mathrm{kg}{ }^{-1} \mathrm{Ni}$ in the form of $\mathrm{NiSO}_{4} \cdot 7 \mathrm{H}_{2} \mathrm{O}, 5.0 \mathrm{mg} \mathrm{kg}{ }^{-1} \mathrm{Mn}$ in the form of $\mathrm{MnSO}_{4}$ and $2.0 \mathrm{mg} \mathrm{kg}^{-1} \mathrm{Zn}$ in the form of $\mathrm{ZnSO}_{4}$. The $\mathrm{K}$ application was split in three equal applications, applied at sowing, and at V2 and R1 phenological stages (Fehr et al., 1971).

After four days, 10 soybean seeds were sown, which had been previously inoculated with $\mathrm{N}_{2}$-fixing bacteria (Bradyrhizobium japonicum), strains SEMIA 587 and 5019. The seeds were evenly covered with a thin soil layer. In phenological stage V1 (Fehr et al., 1971), the plants were thinned to three plants per pot.

To determine field capacity of the pots, five pots were placed in a water box with a volume of water equivalent to $2 / 3$ of the height of the pots for $24 \mathrm{~h}$ in order to complete saturation occurred. Subsequently, the pots were covered with plastic film to avoid evaporation, ensuring water drainage only by gravity. The pots were weighed at $0 \mathrm{~h}$ and after 24,36, 48, 60 and $72 \mathrm{~h}$. The irrigation of the experiment was carried out manually with deionized water, keeping humidity at $80 \%$ of field capacity.

\section{Parameters analyzed}

\section{Growth and grain yield}

The determination of shoot dry mass was carried out through the collection of leaves in senescence during R6 and R7 phenological stages (Fehr et al., 1971), which were incorporated into the material remaining at phenological stage R8 (stalk and leaves) (Fehr et al., 1971). The number of pods per plant was counted at the same stage (R8).

After grain harvest, the number of grains per plant was counted, excluding the empty pods. The weight of 100 grains was obtained from the quotient between the total weight of the grains and the total number of grains multiplied by 100 . The grain yield per pot was estimated from the number of grains produced by each plant in the pot, divided by the number of plants per pot. Grain yield was converted to dry weight with a moisture correction of $13 \%$.

\section{Nutritional analysis}

At the R1 phenological stage, with the beginning of flowering according to Fehr et al. (1971), the first newly expanded trifoliate leaf (counting from the apex) was collected for foliar diagnosis. The leaves were ground in a Wiley mill and the total contents of $\mathrm{N}, \mathrm{P}, \mathrm{K}, \mathrm{Ca}, \mathrm{Mg}$, and S were determined as described by Malavolta et al. (1997).

To determine $\mathrm{N}$, the samples were digested in sulfuric acid $\left(\mathrm{H}_{2} \mathrm{SO}_{4}\right)$, followed by distillation and titration by the semimicro-Kjeldahl method. To determine the contents of $\mathrm{P}, \mathrm{K}, \mathrm{Ca}, \mathrm{Mg}$ and $\mathrm{S}$, the samples were digested in nitric-perchloric acid $165 \% \mathrm{HNO}_{3}$ and $70 \%$ $\mathrm{HClO}_{4}$ ). Atomic absorption spectrophotometry was used to determine the contents of $\mathrm{Ca}$ and $\mathrm{Mg}$, while the $\mathrm{K}$ content was determined by flame photometry. The $\mathrm{P}$ content was obtained by colorimetry and the S content was obtained by barium chloride $\left(\mathrm{BaCl}_{2}\right)$ turbidimetry. The macronutrient concentration was expressed as $\mathrm{g} \mathrm{kg}^{-1}$.

The relationship between the $\mathrm{N}$ and $\mathrm{S}$ leaf contents was also calculated in terms of S levels.

\section{Determination of storage protein}

To extract storage proteins, $0.25 \mathrm{~g}$ of dry and ground grain was weighed and subjected to sequential extraction with $5 \mathrm{~mL}$ of deionized water (for albumin fraction), 5 $\mathrm{mL}$ of $5 \% \mathrm{NaCl}$ (for globulin), $2.5 \mathrm{~mL}$ of $60 \%$ ethanol (for prolamin), and $5 \mathrm{~mL}$ of $0.4 \% \mathrm{NaOH}$ (for glutelin extraction), according to the methodology described by Reis et al. (2018). Protein contents in the extracts were determined according to Bradford (1976), using BSA (bovine serum albumin) as standard. 


\section{Soil analysis}

At the end of the experiment, soil samples were collected from each pot to determine inorganic S-sulfate and $\mathrm{pH}$ of soil, according to the methodology described by Raij et al. (2001).

Inorganic S-sulfate was determined by turbidimetry, using $0.01 \mathrm{~mol} \mathrm{~L}^{-1}$ calcium phosphate $\mathrm{Ca}\left(\mathrm{H}_{2} \mathrm{PO}_{4}\right)_{2}$ extracting solution. For that, $10 \mathrm{~cm}^{3}$ of soil was collected and transferred to plastic flasks, $25 \mathrm{~mL}$ of the extractive solution was added and then $0.25 \mathrm{~g}$ of activated charcoal. Then, flasks were transferred to a table orbital shaker for $30 \mathrm{~min}$ at $220 \mathrm{rpm}$ followed by $30 \mathrm{~min}$ of rest.

After stirring, the sample was filtered with quantitative filter paper (Whatman Grade 42), $10 \mathrm{~mL}$ of the filtered solution and $1 \mathrm{~mL}$ of the acid "seed" solution (20 $\mathrm{mg} \mathrm{L}^{-1}$ of S) were pipetted into plastic flasks. Then, 0.5 $\mathrm{g}$ of barium chloride $\left(\mathrm{BaCl}_{2} \cdot 2 \mathrm{H}_{2} \mathrm{O}\right)$ was added and shaken manually for rea ding in a UV-VIS spectrophotometer $(\lambda=420 \mathrm{~nm})$. The inorganic S-sulfate was calculated based on a standard curve, and the results were expressed in $\mathrm{mg} \mathrm{kg}^{-1}$.

To determine the soil $\mathrm{pH}, 10 \mathrm{~cm}^{3}$ of soil was collected and transferred to plastic flasks. Then, $25 \mathrm{~mL}$ of $0.01 \mathrm{~mol} \mathrm{~L}^{-1}$ calcium chloride solution $\left(\mathrm{CaCl}_{2}\right)$ was added and allowed to rest for $15 \mathrm{~min}$. Subsequently, plastic flasks were transferred to a table orbital shaker for 10 $\mathrm{min}$ at $220 \mathrm{rpm}$ followed by $30 \mathrm{~min}$ of rest. Lastly, the soil $\mathrm{pH}$ was measured through a potentiometer by immersing its electrodes into the sample suspension.

\section{Data analysis}

For all datasets, normality was tested using the Anderson-Darling test and homoscedasticity was tested using the Levene test. The analysis of variance (ANOVA) using the $\mathrm{F}$ test at $p \leq 0.05$ was used to compare the means of the data. When the ANOVA results were significant, the qualitative parameters were tested with the Tukey test $(p<0.05)$ and the regression analysis was performed on the quantitative parameters, testing the linear, quadratic, inverse first order, and exponential models.

All statistical data analysis was performed using routines developed in free $\mathrm{R}$ software (Team, 2018), using the package "ExpDes.pt". Graphs were plotted using SigmaPlot (Systat Software Inc, the United States).

\section{Results}

\section{Crop development and yield}

The number of pods per plant, number of grains per plant, and grain yield per pot parameters showed interactions between $\mathrm{S}$ levels and sources.

GI, GY, and ESPO sources had an inverse first order positive response for the number of pods per plant, number of grains per plant (except ESPO), and grain yield per pot. On the other hand, ESPA had a positive linear response, with percentage increases of 66,58 , and $57 \%$ for the parameters, respectively (Figures 1A, 1B and $1 \mathrm{C})$.
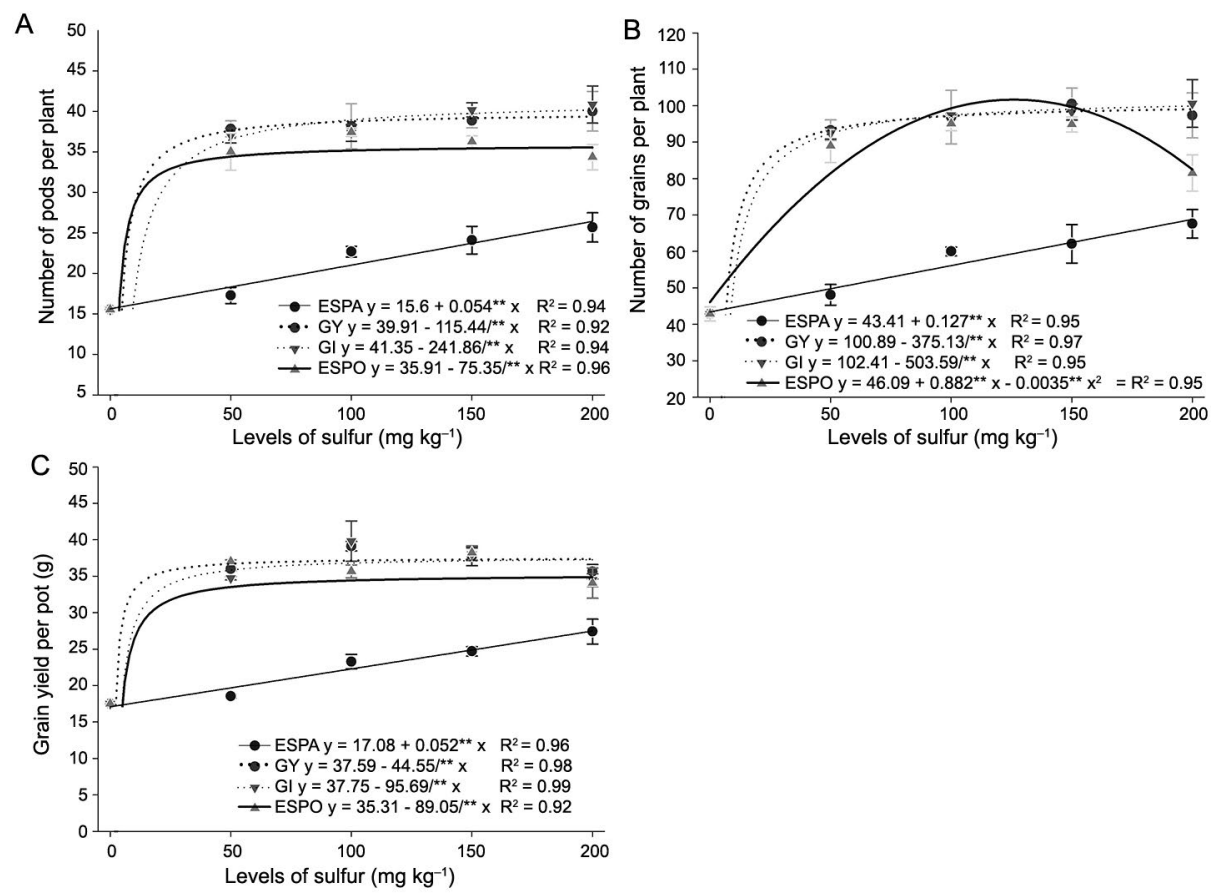

Figure 1 - Interaction effect for the number of soybean pods per plant (A), number of grains per plant (B), and grain yield per pot (C) in soybeans with different $S$ application levels and sources. Sources: elemental S pastille (ESPA), gypsum (GY), gypsite (Gl) and elemental S powder (ESPO). ${ }^{* *} p<0.01$. Vertical bars represent the standard deviation. 
The application of $50 \mathrm{mg} \mathrm{kg}{ }^{-1}$ of $\mathrm{S}$ was sufficient for the maximum yield of pods per plant, number of grains per plant, and yield of grains per pot for GY, GI, and ESPO, except for the number of grains per plant for ESPO, which reached the maximum yield at the level of $126 \mathrm{mg} \mathrm{kg}^{-1}$. Grain yield was $64 \%$ for ESPA, $100 \%$ for GY and GI, and $89 \%$ higher for ESPO compared to untreated soybean plants.

The shoot DM showed an isolated effect for $S$ levels and sources. The shoot DM responses to the $S$ applications were inverse first order positive. The dose of $50 \mathrm{mg} \mathrm{kg}^{-1}$ was sufficient for the maximum yield, and had a maximum yield of $17.7 \mathrm{~g}$, and an increase of $13 \%$ in relation to the control (Figure 2A). The $\mathrm{S}$ sources that obtained the best results were GY and GI, with yield at approximately $11 \%$ greater than the ESPA source (Figure 2B).

The weight of 100 grains was not significantly affected by any factor with an average of $13.15 \mathrm{~g}$.

\section{Nutritional status of soybeans}

The leaf contents of $\mathrm{P}, \mathrm{Ca}, \mathrm{S}$ and the $\mathrm{N}: \mathrm{S}$ ratio indicated interactions between $\mathrm{S}$ levels and sources.

The $\mathrm{P}$ content had different responses for $\mathrm{S}$ sources (Figure 3A). There was a positive linear response to ESPA and positive quadratic responses to ESPO, GY and GI. The maximum content was at the level of $115 \mathrm{~kg}^{-1}$, while GY and GI reached their maximums contents at the dose of $142 \mathrm{~kg}^{-1}$.

The response of $\mathrm{Ca}$ content to the application of GI and ESPO and S levels was negatively quadratic and slightly lower than that of the control (Figure 3B), while GY and ESPA did not influence Ca. The S content was associated with positive quadratic response, with the maximums between 145-185 $\mathrm{mg} \mathrm{kg}^{-1}$ levels, except for ESPA, which was associated with a positive linear response (Figures 3C and 3D).

Regarding the N:S ratio, the ESPA source had a different response for the $\mathrm{N}: \mathrm{S}$ ratio than the other sources (Figure 3E). This behavior is expected due to the values obtained for the contents (Figure 3C) and yield parameters (Figures 1 and 2). The maximum values obtained for the grain yield per pot revealed the best $\mathrm{N}: \mathrm{S}$ ratio at stage $\mathrm{R} 1$, because there was a greater production of grains: 25.5:1 for ESPA, 26.9:1 for GY, 27.2:1 for GI, and 25:2 for the ESPO.

The $\mathrm{N}$ content was affected as an isolated effect for S levels and sources, whereas Mg was affected only by $\mathrm{S}$ sources. The $\mathrm{N}$ content tended to decrease with increasing levels of S (Figure 4A). ESPA showed the greatest contents of the sources, which differed from ESPO, with a greater content of $9 \%$ (Figure 4B). ESPA and ESPO resulted in the greatest $\mathrm{Mg}$ contents, and differed from GI, with greater contents of 16 and $8 \%$, respectively (Figure 4C).

The average $\mathrm{K}$ content was $5.41 \mathrm{~g} \mathrm{~kg}^{-1}$ and it was not significant for $\mathrm{S}$ levels and sources.

\section{Storage protein profile}

The contents of albumin, globulin, prolamin, and glutelin proteins showed interactions between S levels and sources.

The albumin and glutelin fractions had a positive quadratic response to all S sources, the maximum values were observed at levels 133 and $100 \mathrm{mg} \mathrm{kg}^{-1}$ ESPA (297\% and $4 \%$ increase over control, respectively), 129 and $95 \mathrm{mg} \mathrm{kg}^{-1}$ for the GY $(326 \%$ and $7 \%$ increase over control, respectively), 125 and $85 \mathrm{mg} \mathrm{kg}^{-1}$ for the GI (49\% and $28 \%$ increase over control, respectively), and 116 and $73 \mathrm{mg} \mathrm{kg}^{-1}$ for the ESPO (113\% and $9 \%$ increase over control, respectively) (Figures 5A and 5D).

Globulin and prolamin had different responses to $S$ application (Figures 5B and 5C). ESPA was related to a negative quadratic behavior for globulin, with a minimum value at $140 \mathrm{mg} \mathrm{kg}^{-1}$ (21 \% decrease over control), and did not significantly affect prolamin. GY was associated with positive quadratic behavior for both parameters; the maximum values were observed for levels 74 and $129 \mathrm{mg} \mathrm{kg}^{-1}(17 \%$ and $24 \%$ increase over control, respectively). GI was also associated with positive linear behavior for both parameters, providing increases of 26 and $45 \%$ in relation to the control. ESPO
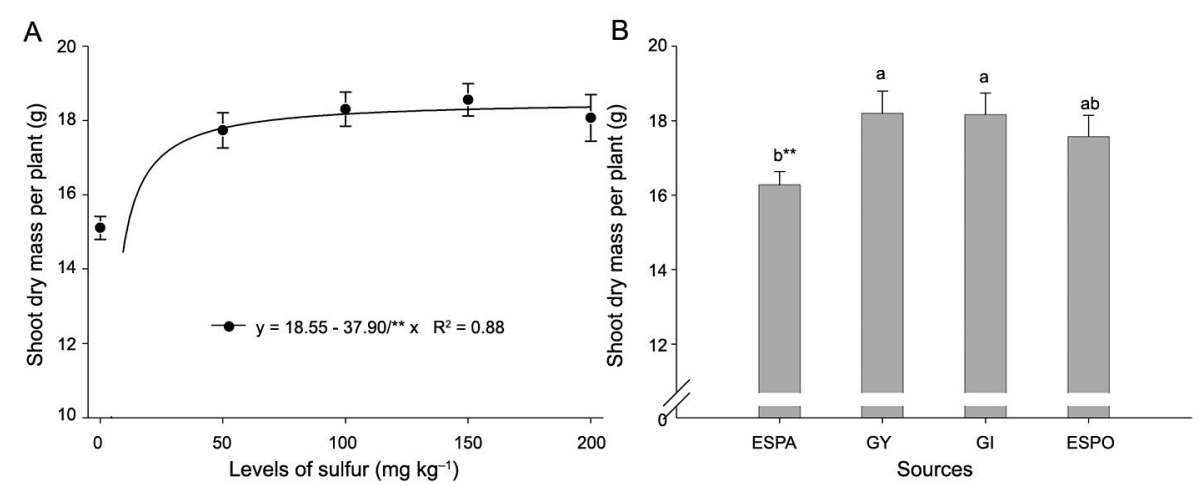

Figure 2 - Isolated effect on dry of soybean shoots in response to $S$ levels (A) and S sources (B), respectively. Sources: elemental S pastille (ESPA), gypsum (GY), gypsite (Gl) and elemental $S$ powder (ESPO). ${ }^{* \star} p<0.01$. Mean values followed by the same letter do not differ significantly by the Tukey test $(p<0.05)$. Vertical bars represent the standard deviation. 

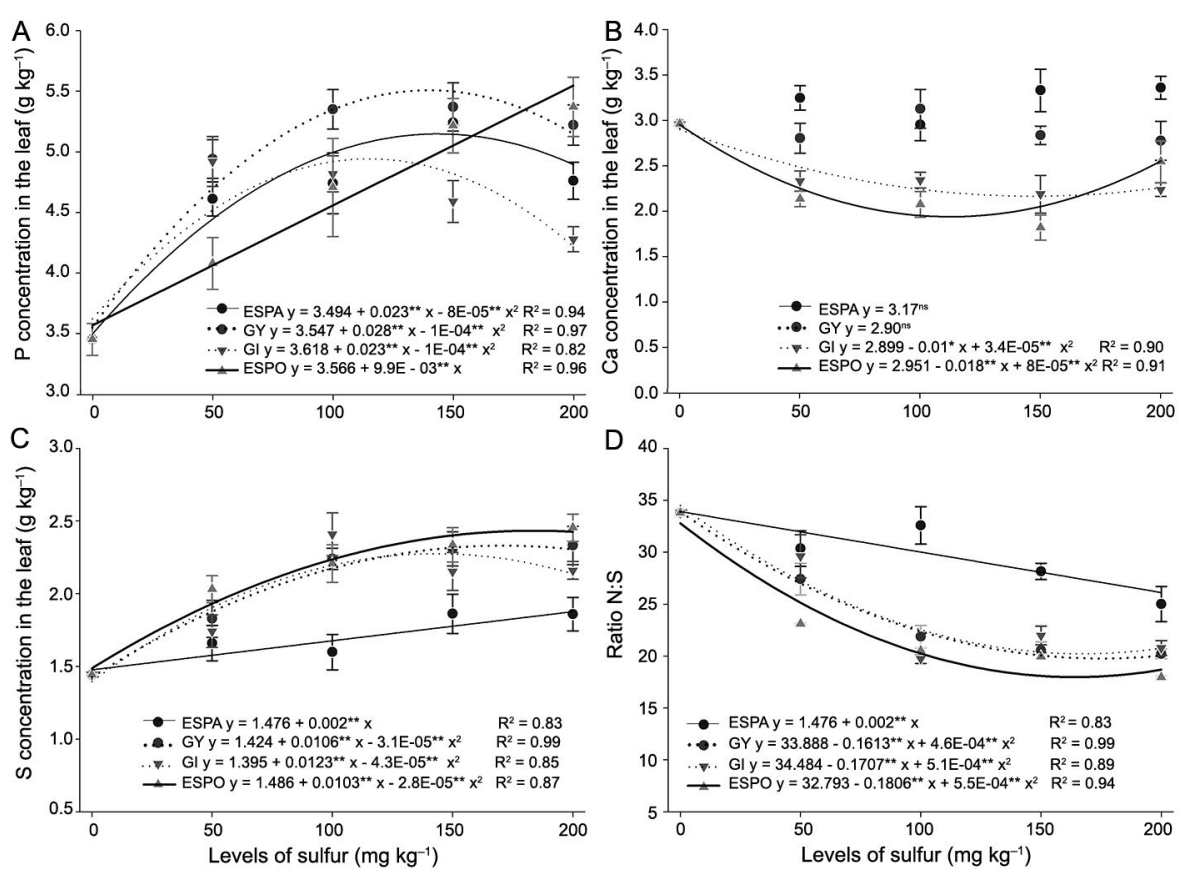

Figure 3 - Interaction effects for phosphorus (A), calcium (B), magnesium (C), and the ratio of N:S (D) contents in soybean leaves in response to $S$ doses and sources. Sources: elemental S pastille (ESPA), gypsum (GY), gypsite (Gl) and elemental S powder (ESPO). ns not significant; ${ }^{*} p<0.05 ;{ }^{*} p<0.01$. Vertical bars represent the standard deviation.
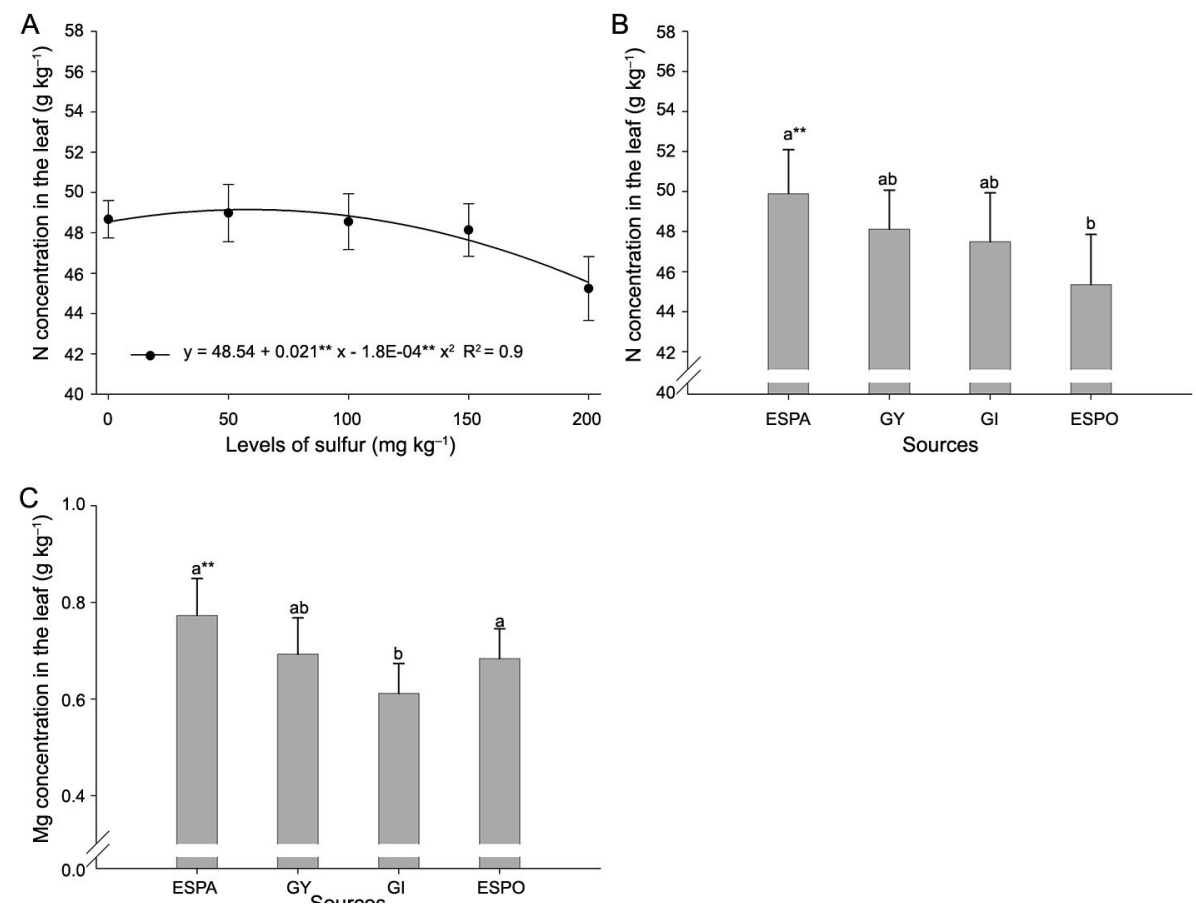

Figure 4 - Isolated effect on soybean leaf nitrogen contents in response to $S$ levels (A) and S sources (B), respectively. Isolated effect on leaf magnesium contents in response to sources of $S(C)$. Sources: elemental $S$ pastille (ESPA), gypsum (GY), gypsite (Gl) and elemental $S$ powder (ESPO). ${ }^{* *} p<0.01$. Mean values followed by the same letter do not differ by the Tukey test $(p<0.05)$. Vertical bars represent the standard deviation. 
was correlated with positive quadratic behavior for globulin protein, with a maximum value at the dose 130 $\mathrm{mg} \mathrm{kg}^{-1}$ (16\% increase over control), and was linearly positive for the prolamin protein, providing increases of $42 \%$ (Figures $5 \mathrm{~B}$ and $5 \mathrm{C}$ ).

\section{Soil}

The inorganic S-sulfate and $\mathrm{pH}$ of soil showed interactions between S levels and sources.

The inorganic S-sulfate in the soil increased in response to S levels application. GY and ESPA were adjusted to a positive linear model, while the other sources were adjusted to the exponential model (Figure $6 \mathrm{~A})$. With the application of $200 \mathrm{mg} \mathrm{kg}^{-1}$, the contents were 29, 56, 80, and $70 \mathrm{mg} \mathrm{kg}^{-1}$ for ESPA, GY, GI and ESPO, respectively.

The $\mathrm{pH}$ values had similar behaviors with the application of ESPA, GY and ESPO and were adjusted to the negative linear model, with reductions of 5.5 and $8 \%$, respectively. GI was adjusted to the negative quadratic model, with a reduction of $10 \%$ in relation to the control for the application of $126 \mathrm{mg} \mathrm{kg}^{-1}$ (Figure 6B).

\section{Discussion}

\section{Crop development and yield}

The results of this study reveal that the exogenous application of S in S-deficient soils provides greater plant
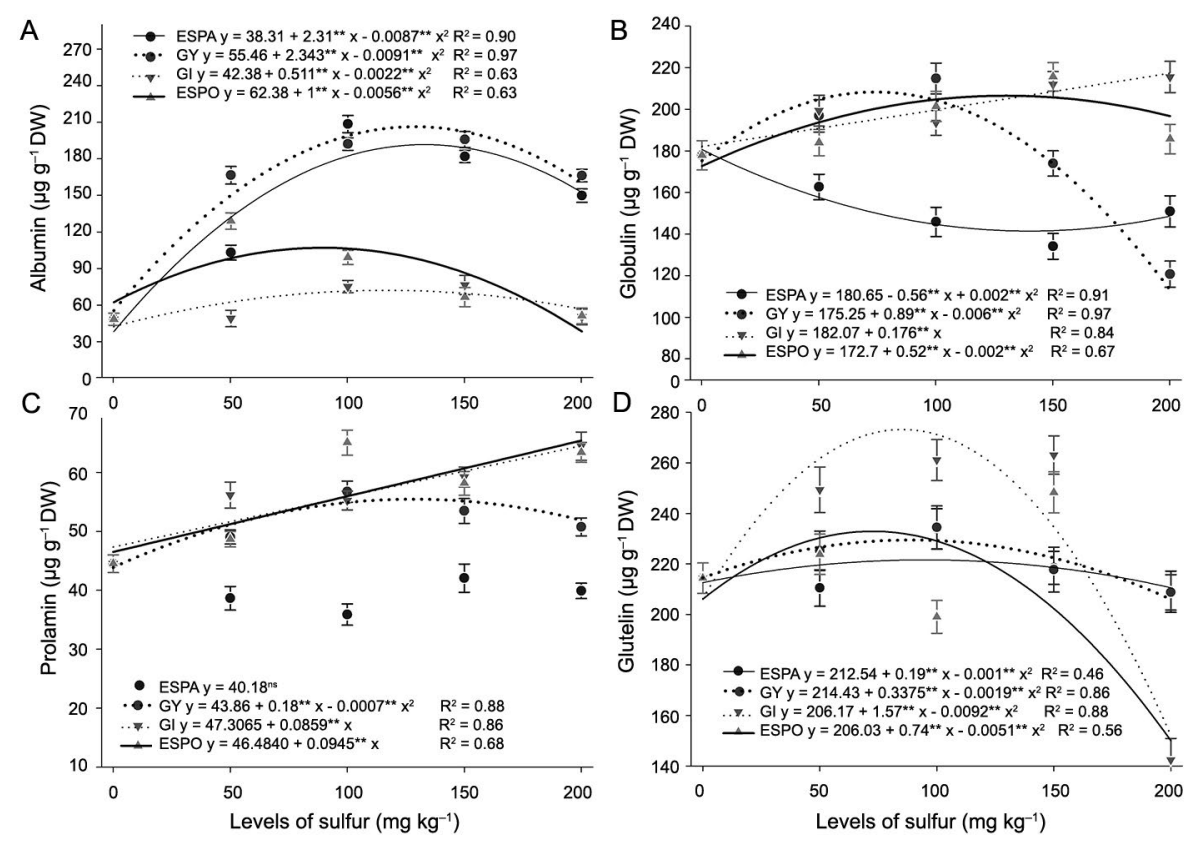

Figure 5 - Interaction effects for soybean grain albumin (A), globulin (B), prolamin (C), and glutelin (D) contents in response to $S$ levels and sources. Sources: elemental S pastille (ESPA), gypsum (GY), gypsite (Gl) and elemental S powder (ESPO). ${ }^{*} p<0.05 ;{ }^{*} p<0.01$. Vertical bars represent the standard deviation.
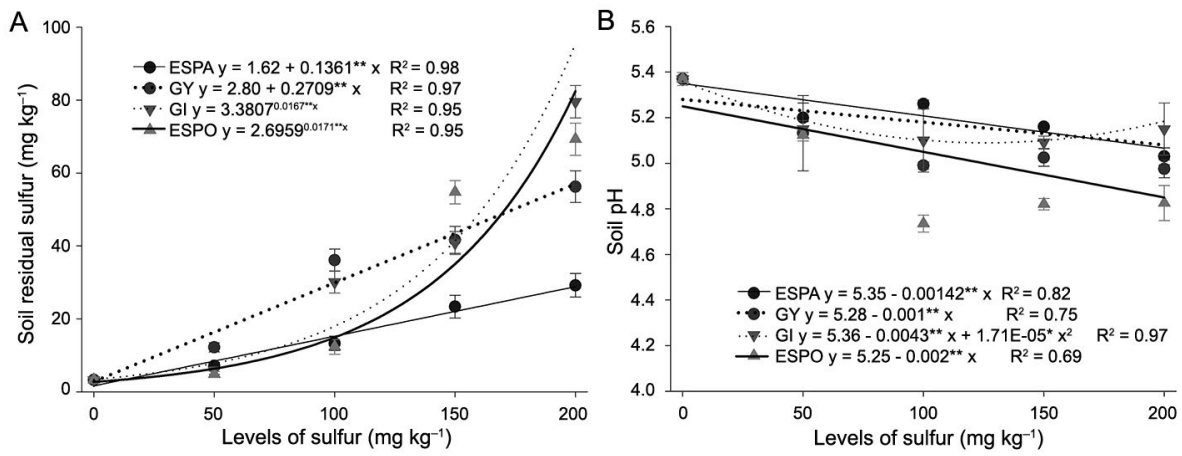

Figure 6 - Interaction effects for inorganic S-sulfate $(A)$ and $\mathrm{pH}(\mathrm{B})$ of soil in response to $\mathrm{S}$ levels and sources after soybean cultivation. Sources: elemental S pastille (ESPA), gypsum (GY), gypsite (GI) and elemental S powder (ESPO). ${ }^{*} p<0.05$; ${ }^{*} p<0.01$. Vertical bars represent the standard deviation. 
growth and grain yield (Figures 1 and 2). These increases are related to $\mathrm{S}$ functions inherent to the catalytic, regulatory, and structural uses by the plant (Capaldi et al., 2015) and can also be related to the fact that $S$ maximizes the nitrogenase enzyme activity in S-deficient soils (Devi et al., 2012).

Previous studies on soybeans in a greenhouse support our study results. Zhao et al. (2008) observed that the S supply significantly increased soybean crop yield, including the weight of 100 grains. Chandra and Pandey (2016) applied sulfate levels to the soil and found that S was essential for development and yield at ideal levels at 26 and 50 days, while lower and higher levels were either insufficient or harmful to soybean plants, respectively. Broch et al. (2011) also found similar results for soybean yield in response to $S$ supplied under field conditions.

Another key factor identified in this study was the differential responses of increase in the number of pods per plant, number of grains per plant, and grain yield per pot in term of the different forms of $S$ provided (elemental S and sulfate) and their respective particle size (Figures 1 and 2). Although all S sources increased the aforementioned parameters, responses varied between the sources, especially with the application of ESPA, which provided smaller values for these parameters than the other sources did.

Based on these results, we suggest that the differential response was associated to particle size of ESPA, since the ESPA fertilizer is granular and ESPO is powder; however, this factor does not change the availability of S with GY and GI, because they are sulfates. This hypothesis is supported by ESPA and ESPO, as they are composed of the same $S$ form (elemental S) and have still differed statistically from each other (Figure 1). These results corroborate with those of Karamanos and Janzen (1991) and Wen et al. (2001).

According to Degryse et al. (2016), a smaller particle size provides a larger contact surface, resulting in a greater possibility of reacting with the soil solution, thereby favoring elemental S oxidation uptake and, consequently, plant development. In addition, elemental S sources are subordinate to abiotic and biotic factors that affect the microbial activity, which influences supply to the plant during its life cycle (Brahim et al., 2017; Degryse et al., 2017).

\section{Nutritional status of soybeans}

The negative quadratic response observed in the $\mathrm{N}$ concentration was probably due to a dilution effect (Figure 3A), because S promoted an increase in the shoot DM (Figure 2A).

The increase in $\mathrm{P}$ concentration could possibly be related to greater root production, which favors soil exploration, especially for $\mathrm{P}$, through which infiltration into the root occurs, mainly by diffusion (Fageria and Moreira, 2011). In addition, fertilization with elemental $S$ increases the number of soil microorganisms and phosphatase enzyme activity, promoting organic $\mathrm{P}$ mineralization during the middle and late stages of the soybean growth (Zhao et al., 2008), which explains the positive linear behavior in response to ESPO.

According to Malavolta et al. (1997), although the contents of $\mathrm{N}, \mathrm{P}, \mathrm{Ca}, \mathrm{S}$ and $\mathrm{Mg}$ varied (Figures $3 \mathrm{~A}, 3 \mathrm{~B}$, $3 \mathrm{C}, 4 \mathrm{~A}, 4 \mathrm{~B}$, and $4 \mathrm{C}$ ), all values remained within the established range adequate for soybean, except for the $S$ content in the leaf with ESPA (Figure 3C), which was reflected in a minor increment in yield values in relation to the other sources (Figures 1 and 3). Therefore, these results show the need to meet the nutritional requirement of $S$ to achieve greater yields.

For our study, the greatest $\mathrm{N}: \mathrm{S}$ ratio was observed in the control, with $33.7: 1$, which could be related to $\mathrm{S}$ deficiency in the soil, because high $\mathrm{N}: \mathrm{S}$ ratios cause the accumulation of amines, amides, and amino acids soluble in the plant due to the non-conversion of $\mathrm{N}$ into protein (Bona et al., 2013; Fageria, 2001). As the S levels increased, there was a decrease in the N:S ratio and soybean yield (Figures 1 and 2). These effects observed in the $\mathrm{N}: \mathrm{S}$ ratios were in agreement with the findings of Steinfurth et al. (2012) for wheat. According to Jamal et al. (2010), the N:S ratio was more sensitive to the variation in $\mathrm{S}$ supply than to $\mathrm{N}$ application and plant age. The authors also concluded that the ideal $\mathrm{N}: \mathrm{S}$ ratio is 14 to $16: 1$, and this value was lower than that observed in this study.

\section{Storage proteins}

Increases in the albumin, globulin, prolamin, and glutelin fractions in the soybean grain were observed with all S sources tested (Figure 6), except for ESPA for globulin and prolamin. This result was expected because $S$ regulates the seed protein storage metabolism (Chandra and Pandey, 2016), as well as because S acts in synergy with $\mathrm{N}$ (Jamal et al., 2010), which is the main nutrient used in protein synthesis.

The lowest contents of globulin, prolamin, and glutelin proteins were observed with ESPA. This effect is probably related to $S$ content in the leaf (Figure $3 \mathrm{C})$, because this $S$ source was below the adequate interpretation range. In particular, the content of globulin protein decreased with the application of ESPA, which can be attributed to the lack of $S$ for cysteine synthesis, as amino acid is a major component of the globulin protein (Chandra and Pandey, 2016).

\section{Soil}

In the control treatment, before soybean cultivation, contents of sulfate in the soil were below the required level for the soybean crop $\left(7 \mathrm{mg} \mathrm{kg}^{-1}\right.$ ) (Reuter and Robinson, 1997), which is attributed to the low clay contents in the soil and organic matter. After the crop cycle, in all sources, a short cultivation time of reduced inorganic S-sulfate contents, with decreases ranging from $51-77 \%\left(1.6-3.4 \mathrm{mg} \mathrm{kg}^{-1}\right)$, which could even lead to $\mathrm{S}$ deficiency in less demanding crops (Figure 6A). On the other hand, with the application of $S$, the inorganic S-sulfate was above the level considered sufficient for 
demanding crops with all sources (Figure 6A). Kopittke et al. (2016) reported that the continuous mineralization of organic $S$ is insufficient to meet the needs of crops, especially in soils with low OM content. Therefore, the application of $\mathrm{S}$ fertilizers is necessary to remedy their scarcity in the soil to provide proper crop nutrition.

The lower sulfate availability detected with the application of ESPA when compared to ESPO can be explained by the particle size. The larger the particle size, the slower the oxidation rate and less $\mathrm{S}$ is available to the plant.

A soil $\mathrm{pH}$ reduction was observed after the harvesting experiment, which can be attributed to the higher base extraction, especially as yield increased (Ahmed, et al., 2017). ESPO was related to a marked reduction of $\mathrm{pH}$ due to its physical and particle size properties, which were related to $\mathrm{S}$ oxidation that released sulfate and hydrogen protons into the soil (Boaro et al., 2014).

\section{Conclusion}

The results show that the ideal application of $\mathrm{S}$ is essential to optimize soybean yield. The low supply of $S$ resulted in lower yield for all tested S sources.

ESPA is not recommended as S source because the $S$ content in the leaf was below the adequate range for soybean plants, resulting in lower yield values.

The particle size of ESPA and ESPO fertilizers was a key factor for the availability of $S$ to soybeans.

Sulfur deficiency was observed at all levels of ESPA, which resulted in lower globulin protein synthesis and an increased albumin fraction. The application of the other sources (GY, GI, and ESPO), in general, increased all storage protein fractions analyzed.

\section{Authors' Contributions}

Conceptualization: Santos, L.F.M.; Lapaz, A.M.; Reis, A.R; Moreira, A.; Heinrichs, R. Data acquisition: Ibañez, T.B.; Santos, L.F.M.; Virgilio, I.R.; Virgilio, F.R.; Heinrichs, R. Design of methodology: Ibañez, T.B.; Santos, L.F.M.; Lapaz, A.M.; Virgilio, I.R.; Reis, A.R; Moreira, A.; Heinrichs, R. Software development: Ibañez, T.B.; Santos, L.F.M.; Lapaz, A.M.; Virgilio, F.R.; Heinrichs, R. Writing and editing: Ibañez, T.B.; Santos, L.F.M.; Lapaz, A.M.; Virgilio, I.R.; Virgilio, F.R.; Reis, A.R; Moreira, A.; Heinrichs, R.

\section{References}

Ahmed, H.P.; Schoenau, J.J.; King T.; Kar, G. 2017. Effects of seed-placed sulfur fertilizers on canola, wheat, and pea yield; sulfur uptake; and soil sulfate concentrations over time in three prairie soils. Journal of Plant Nutrition 40: 543-557.

Aziz, M.; Nadipalli, R.K.; Xie, X.; Sun, Y.; Surowiec, K.; Zhang, J.L.; Paré, P.W. 2016. Augmenting sulfur metabolism and herbivore defense in Arabidopsis by bacterial volatile signaling. Frontiers in Plant Science 7: 458.
Balk, J.; Pilon, M. 2011. Ancient and essential: the assembly of iron-sulfur clusters in plants. Trends in Plant Science 16: 218-226.

Boaro, V.; Schwarz, S.F.; Souza, P.V.D.D.; Soares, W.; Lourosa, G.V. 2014. Elemental sulfur for $\mathrm{pH}$ management of alcaline organic substrates. Ciência Rural 44: 2111-2117 (in Portuguese, with abstract in English).

Bona, F.D.; Schmidt, F.; Monteiro, F.A. 2013. Importance of the nitrogen source in the grass species Brachiaria brizantha responses to sulfur limitation. Plant and Soil 373: 201-216.

Bradford, M.M. 1976. A rapid and sensitive method for the quantitation of microgram quantities of protein utilizing the principle of protein-dye binding. Analytical Biochemistry 72 : 248-254.

Brahim, S.; Niess, A.; Pflipsen, M.; Neuhoff, D.; Scherer, H. 2017. Effect of combined fertilization with rock phosphate and elemental sulphur on yield and nutrient uptake of soybean. Plant, Soil and Environment 63: 89-95.

Broch, D.L.; Pavinato, P.S.; Possentti, J.C.; Martin TN, Quiqui, E.M.D. 2011. Soybean grain yield in cerrado region influenced by sulphur sources. Revista Ciência Agronômica 42: 791-796 (in Portuguese, with abstract in English).

Capaldi, F.R.; Gratão, P.L.; Reis, A.R.; Lima, L.W.; Azevedo, R.A. 2015. Sulfur metabolism and stress defense responses in plants. Tropical Plant Biology 8: 60-73.

Cazzato, E.; Laudadio, V.; Stellacci, A.M.; A.M.; Ceci, E.; Tufarelli, V. 2012. Influence of sulphur application on protein quality, fatty acid composition and nitrogen fixation of white lupin (Lupinus albus L.). European Food Research and Technology 235: 963-969.

Chandra, N.; Pandey, N. 2016. Role of sulfur nutrition in plant and seed metabolism of Glycine max L. Journal of Plant Nutrition 39: 1103-1111.

Degryse, F.; Ajiboye, B.; Baird, R.; Silva, R.C.; McLaughlin, M.J. 2016. Oxidation of elemental sulfur in granular fertilizers depends on the soil-exposed surface area. Soil Science Society of America Journal 80: 294-305.

Degryse, F.; Silva, R.C.; Baird, R.; Beyrer, T.; Below, F.; McLaughlin, M.J. 2017. Uptake of elemental or sulfate-S from fall- or springapplied co-granulated fertilizer by corn: a stable isotope and modeling study. Field Crops Research 221: 322-332.

Devi, K.N.; Singh, L.N.K.; Singh, S.M.; Singh, S.B.; Singh, K.K. 2012. Influence of sulphur and boron fertilization on yield, quality, nutrient uptake and economics of soybean (Glycine max) under upland conditions. Journal of Agricultural Science 4: $1-10$.

Divito, G.A.; Echeverría, H.E.; Andrade, F.H.; Sadras, V.O. 2015. Diagnosis of S deficiency in soybean crops: Performance of S and N: S determinations in leaf, shoot and seed. Field Crops Research 180: 167-175.

Fageria, N.K.; Moreira, A. 2011. The role of mineral nutrition on root growth of crop plants. Advances in Agronomy 100: 251-331.

Fageria, V.D. 2001. Nutrient interactions in crop plants. Journal of Plant Nutrition 24: 1269-1290.

Fehr, W.R.; Caviness, C.E.; Burmood, D.T.; Pennington, J.S. 1971. Stage of development descriptions for soybeans, Glycine Max (L.) Merrill. Crop Science 11: 929-931. 
Habtemichial, K.H.; Ram Singh, B.; Aune, J.B. 2007. Wheat response to $\mathrm{N}_{2}$ fixed by faba bean (Vicia faba L.) as affected by sulfur fertilization and rhizobial inoculation in semi-arid Northern Ethiopia. Journal of Plant Nutrition and Soil Science 170: 412-418.

Jamal, A.; Moon, Y.S., Zainul Abdin, M. 2010. Sulphur: a general overview and interaction with nitrogen. Australian Journal of Crop Science 4: 523-529.

Karamanos, R.E.; Janzen, H.H. 1991. Crop response to elemental sulfur fertilizers in central Alberta. Canadian Journal of Soil Science 71: 213-225.

Kopittke, P.M.; Dalal, R.C.; Menzies, N.W. 2016. Sulfur dynamics in sub-tropical soils of Australia as influenced by long-term cultivation. Plant and Soil 402: 211-219.

Malavolta, E.; Vitti, G.C.; Oliveira, S.A. 1997. Evaluation of the Nutritional State of Plants: Principles and Applications = Avaliação do Estado Nutricional de Plantas: Princípios e Aplicações. 2ed. Potafos, Piracicaba, SP, Brazil (in Portuguese).

Liu, C.; Wang, X.; Ma, H.; Zhang, Z.; Gao, W.; Xiao, L. 2008. Functional properties of protein isolates from soybeans stored under various conditions. Food Chemistry 111: 29-37.

Quaggio, J.A.; Raij, B.van.; Malavolta, E. 1985. Alternative use of the SPM: buffer solution to determine lime requirement of soil. Communications in Soil Science and Plant Analysis 16: 245-260.

Raij, B. van.; Andrade J.C.; Cantarela H, Quaggio, J.A. 2001. Chemical Analysis for Tropical Soil Fertility = Análise Química para Fertilidade de Solos Tropicais. Instituto Agronômico, Campinas, SP, Brazil (in Portuguese).

Reis, H.P.G.; Barcelos, J.P.Q.; Furlani Junior, E.; Santos, E.F.; Silva, V.M.; Moraes, M.F.; Putti, F.F.; Reis, A.R. 2018. Agronomic biofortification of upland rice with selenium and nitrogen and its relation to grain quality. Journal of Cereal Science 79: 508515 .
Reuter, D.; Robinson, J.B. 1997. Plant Analysis: An Interpretation Manual. 2ed. CSIRO, Melbourne, Australia.

Salvagiotti, F.; Ferraris, G.; Quiroga, A.; Barraco, M.; Vivas, H.; Prystupa, P.; Echeverría, H.; Boem, F.H.G. 2012. Identifying sulfur deficient fields by using sulfur content; N: S ratio and nutrient stoichiometric relationships in soybean seeds. Field Crops Research 135: 107-115.

Shoemaker, H.E.; McLean, E.O.; Pratt, P.F. 1961. Buffer methods for determination of lime requirements of soils with appreciable amount of exchangeable aluminum. Soil Science Society of America Journal 25: 274-277.

Steinfurth, D.; Zörb, C.; Braukmann, F.; Mühling, K.H. 2012. Time-dependent distribution of sulphur, sulphate and glutathione in wheat tissues and grain as affected by three sulphur fertilization levels and late $S$ fertilization. Journal of Plant Physiology 169: 72-77.

Vermeiren, C.; Smolders, E.; McLaughlin, M.J.; Degryse, F. 2018. Model-based rationalization of sulphur mineralization in soils using $35 \mathrm{~S}$ isotope dilution. Soil Biology and Biochemistry 120: 1-11.

Wen, G.; Schoenau, J.J.; Yamamoto, T.; Inoue, M. 2001. A model of oxidation of an elemental sulfur fertilizer in soils. Soil Science 166: 607-613

Zhao, Y.; Xiao, X.; Bi, D.; Hu, F. 2008. Effects of sulfur fertilization on soybean root and leaf traits, and soil microbial activity. Journal of Plant Nutrition 31: 473-483. 